\title{
Absorption of cumene through the respiratory tract and excretion of dimethylphenylcarbinol in urine
}

\author{
WITOLD SEŃCZUK and BARBARA LITEWKA \\ Department of Toxicological Chemistry, Institute of Chemistry and Analytical Science, \\ Academy of Medicine, Poznań, ul. Grunwaldzka 6, Poland
}

\begin{abstract}
Seńczuk, W. and Litewka, B. (1976). British Journal of Industrial Medicine, 33, 100-105. Absorption of cumene through the respiratory tract and excretion of dimethylphenylcarbinol in urine. Experiments on the absorption of cumene and the excretion of dimethylphenylcarbinol were made on 10 healthy volunteers, five men and five women aged between 20 and 35 years. They were exposed to cumene vapours $240,480,720 \mathrm{mg} / \mathrm{m}^{3}$ under controlled conditions. It was found that the average retention of cumene vapours was about $50 \%$ which tended to diminish at the end of each exposure. Based on these results, an exposure test that allows one to calculate the absorbed cumene dose during eight hours' work with a precision of about \pm $13 \cdot 5 \%$ was achieved.
\end{abstract}

The normal methods of evaluating occupational exposure have been based mainly on studies of concentrations of toxic compounds in air, while the interpretation of results has been made by comparing the highest permissible concentrations according to the industrial standard of the chemical in a factory.

The risk of intoxication depends mainly on the amount of the chemical that can be absorbed by the body each day, which is not always simply correlated with the concentration of that chemical in air. When the chemical is absorbed by means other than the respiratory tract the determination of the concentration of toxic compounds in air may have only a partial relevance when evaluating the exposure to the chemical.

More and more biochemical indices of absorption are being established; these are based on kinetics of absorption and excretion of chemicals or their metabolites by the system. The most developed form of a quantitative test is the integrated index of absorption (Dutkiewicz, 1971). This test is based on a previous conclusion that there is a correlation, without regard to the route of absorption and ex- cretion, between the absorbed dose of the toxic compound and the excreted amount of its metabolite in the biological material. Biochemical indices of absorption allow the exposure to toxic compounds to be precisely calculated irrespective of the route of absorption, even when it takes place simultaneously by all possible routes (Ader, Piotrowski, and Zaremba, 1958; Salmowa and Piotrowski, 1960; Dutkiewicz, 1962).

Robinson, Smith, and Williams (1955) showed in experiments on rabbits that cumene introduced by way of the digestive system was metabolized in the liver. The metabolites form glucuronides and are subsequently excreted in urine. About $40 \%$ of cumene is converted into 2-phenylpropandiol(dimethylphenylcarbinol); $25 \%$ of $\alpha$-phenylpropionic acid and $25 \%$ of 2-phenylpropandiol are also formed in the same amounts (Fig. 1).

We aimed at working out a test based on measurements of the rate of excretion of dimethylphenylcarbinol in urine, and at determining the amount of cumene absorbed via the respiratory tract in industrial conditions. 


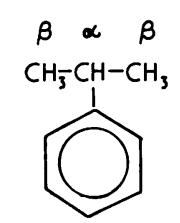

Isopropylbenzene

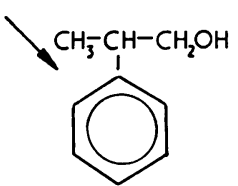

Methylbenzylcarbinol (25\%)

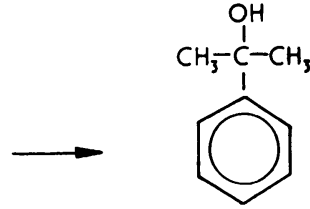

Dimethylphenycorbinol $(40 \%)$

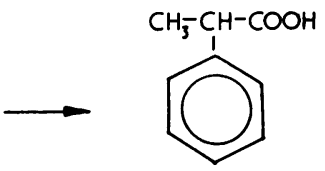

2-phenylpropionic acid $(25 \%)$
FIG. 1. Metabolism of cumene.

\section{Methods}

Thirty experiments were carried out on 10 volunteers; five were men and five were women aged between 20 and 35 years. Medical examinations showed that they were in good health. These people had had no contact with toxic compounds and had not used any drugs during the period before the experiments. The exposure to cumene vapours was done in an experimental chamber, especially constructed and adjusted for inhalation examinations on people (Seńczuk and Orłowski, 1976). A defined concentration of cumene vapours in the chamber was obtained by proportioning by weight, cumene being evaporated at a constant rate in a vessel placed in an ultrathermostat.

During exposure the subject sat with his head in the chamber. The exposure lasted eight hours which was divided into three periods. The first two periods each lasted two and a half hours, the third two hours. After each of the first two periods there was a break of 30 minutes so that the exposed person could have his meal and drink a cup of tea or coffee. Every 10 days each subject was exposed to one of three different concentrations of cumene $\left(240,480,720 \mathrm{mg} / \mathrm{m}^{3}\right)$. The concentration of cumene in the inhaled and expired air was determined in all subjects by gas chromatography. The samples of expired air, $10 \mathrm{~cm}^{3}$, were collected by means of a pipe placed in the front wall of the toxicological chamber. Through this pipe the subject in the chamber exhaled air during examination. The measurements were made during the initial phase of exposure and near its end. The urine was collected for examination during and after exposure, that is $2 \cdot 5,5 \cdot 5,8,10,12,14,24,32,40$, and 48 hours after the exposure began. The specific gravity of each urine fraction was determined by means of a urometer.

Cumene vapours in the experimental chamber and in exhaled air

The determination was done using Giede's apparatus for gas chromatography model GCH 18.3 fitted with a flame ionization detector. A column $3 \mathrm{~m} \times 4 \mathrm{~mm}$ was used, the stationary phase was $15 \%$ Apiezon grease on Chromosorb $\mathrm{W}$. The temperature of the column was $130^{\circ}$, that of the injection post $210^{\circ}$. The rate of flow of the carrier gas (nitrogen) was $50 \mathrm{~cm}^{3} / \mathrm{min}$ and that of hydrogen $50 \mathrm{~cm}^{3} /$ min. One determination lasted about six minutes.

A standard atmosphere, $1 \mu \mathrm{g} / \mathrm{cm}^{3}$ was prepared in a glass bottle $32.7 \mathrm{dcm}^{3}$. The calibration curve was constructed by static method, taking different volumes of air from the bottle with a syringe, and injecting it into the chromatograph. Simultaneously a standard solution of cumene in ether was prepared, and the appropriate standard calibration curve was made. Using a Zimmermann syringe 2, 4, 6, 8, $10 \mathrm{~cm}^{3}$ of ether were injected, corresponding to $2,4,6,8,10 \mu \mathrm{g}$ of cumene. The method for determining cumene in air was precise within $\pm 8.5 \%$, and for cumene in ether $\pm 7.2 \%$. Standard calibration curves are shown in Fig. 2.

It was found that the results for cumene in air were about $41 \%$ lower than those for cumene in ether. To determine the precise amount of cumene in air, the results were multiplied by the coefficient 1.65 (Table 1 ).

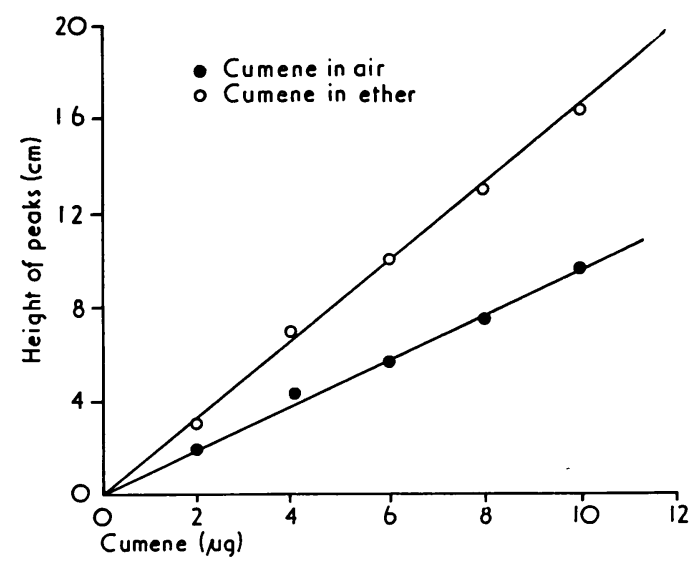

FIG. 2. Calibration curves of cumene determined by gas chromatography.

TABLE 1

Relationship Between Cumene Peaks and Concentration of Cumene in Air and in ETHER

\begin{tabular}{|c|c|c|c|c|c|}
\hline \multirow[t]{3}{*}{ No. } & \multirow{3}{*}{$\begin{array}{l}\text { Dimethyl- } \\
\text { phenyl- } \\
\text { carbinol } \\
(\mathrm{mg})\end{array}$} & \multicolumn{3}{|c|}{ Cumene } & \multirow{3}{*}{$\begin{array}{c}\text { Co- } \\
\text { effi- } \\
\text { cient } \\
\frac{B}{A}\end{array}$} \\
\hline & & \multicolumn{2}{|c|}{$\begin{array}{c}\text { Mean height of } \\
\text { peaks }\end{array}$} & \multirow{2}{*}{$\begin{array}{l}\text { (\%) de- } \\
\text { crease of } \\
\text { height of } \\
\text { peaks in } \\
\text { air }\end{array}$} & \\
\hline & & $\operatorname{Air} A$ & $\begin{array}{c}\text { Ether } \\
B\end{array}$ & & \\
\hline $\begin{array}{l}1 \\
2 \\
3 \\
4 \\
5 \\
6\end{array}$ & $\begin{array}{c}2 \\
4 \\
6 \\
8 \\
10 \\
\text { Mean }\end{array}$ & $\begin{array}{l}1.9 \\
4 \cdot 3 \\
5 \cdot 6 \\
7 \cdot 5 \\
9 \cdot 5\end{array}$ & $\begin{array}{r}3.0 \\
6.9 \\
10.0 \\
13.0 \\
16 \cdot 3\end{array}$ & $\begin{array}{l}37 \\
41 \\
44 \\
42 \\
41 \\
41\end{array}$ & $\begin{array}{l}1.57 \\
1.6 \\
1.78 \\
1.73 \\
1.6 \\
1.65\end{array}$ \\
\hline
\end{tabular}




\section{Dimethylphenylcarbinol in urine}

The urine of people exposed to cumene was acidified to pH 2 and hydrolyzed for 15 minutes in a bath of boiling water. After cooling, the hydrolysate was adjusted to $\mathrm{pH}$ 8 and extracted with ether in the apparatus continuously for four hours. The ether extracts were collected in 10 $\mathrm{cm}^{3}$ flasks. The dimethylphenylcarbinol in the extracts was determined using the Giede gas chromatograph, model GCHF 18.3. The column was $3 \mathrm{~m} \times 4 \mathrm{~mm}$, filled with chromosorb W with Apiezon L grease $(15 \%)$ as the stationary phase. The chromatograph had an ionization-flame detector. The temperature of the column was $130^{\circ} \mathrm{C}$, and that of the injection chamber $210^{\circ} \mathrm{C}$. The rate of flow of both the carrier gas (nitrogen) and the hydrogen was $50 \mathrm{~cm}^{3} / \mathrm{min}$.

A calibration curve was constructed by adding known amounts of a standard solution of dimethylphenylcarbinol to urine. The concentrations of dimethylphenylcarbinol were calculated as the mean of three measurements of the areas of the peaks. The areas of peaks were calculated as the product of height and peak width at half height. The mean precision of the method in the range 2 to $20 \mu \mathrm{g}$ was $\pm 7 \cdot 3 \%$; the precision of determining the smallest amount of the examined substance $(2 \mu \mathrm{g})$ was $\pm 10 \cdot 5 \%$ (Fig. 3 ).

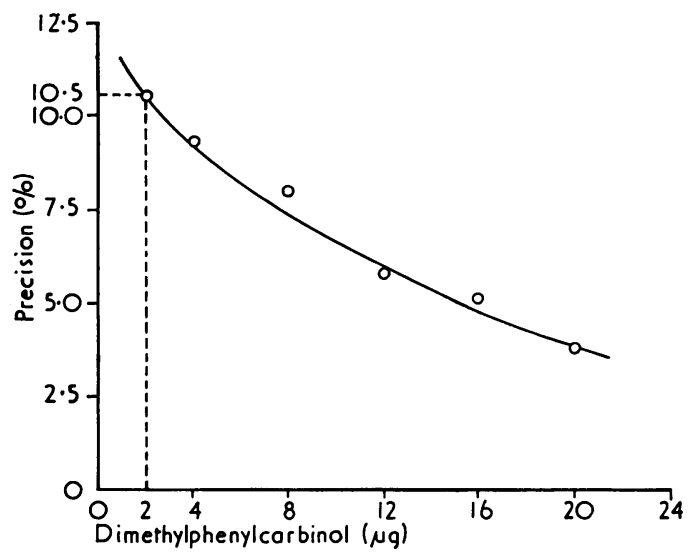

FIG. 3. Dependence between variation coefficient and amount of dimethylphenylcarbinol.

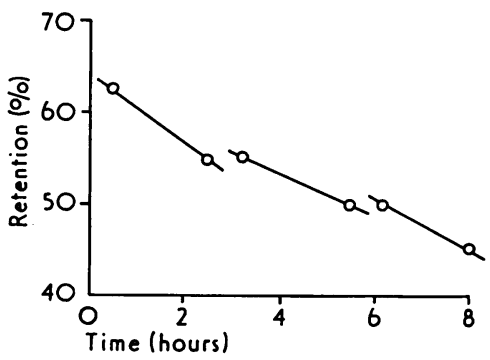

FIG. 4. Retention of cumene vapours in lungs during eight hours' exposure.

\section{Results}

The concentration of cumene vapours in the chamber was stable and ranged between $\pm 5 \%$ of the mean concentration in the experiment.

The retention of cumene vapours in the respiratory tract ranged from $64 \%$ to $45 \%$ (mean $50 \%$ ) depending on the time of exposure.

No dimethylphenylcarbinol was found in the urine of the exposed subjects before the experiment. The amounts of absorbed cumene are shown for the three concentrations of cumene in the air in Table 2, taking into account retention, ventilation of lungs, and time of exposure.

The results have shown a directly proportional dependence between the absorbed dose of cumene and the amount of the excreted metabolite, that is dimethylphenylcarbinol (Fig. 5).

\section{TABLE 2}

Amount of Absorbed Cumene During Eight Hours' Exposure, According to Cumene CONCENTRATION IN Air

\begin{tabular}{|c|c|c|}
\hline Sex & $\begin{array}{l}\text { Concentration of } \\
\text { cumene in chamber } \\
\left(\mathrm{mg} / \mathrm{m}^{3}\right)\end{array}$ & $\begin{array}{c}\text { Mean absorbed } \\
\text { cumene }(\mathrm{mg})\end{array}$ \\
\hline Women & $\begin{array}{r}240 \\
480 \\
720\end{array}$ & $\begin{array}{c}270 \cdot 8 \\
(202 \cdot 0-386 \cdot 0)^{*} \\
526 \cdot 0 \\
(404 \cdot 0-772 \cdot 0) \\
789 \cdot 0 \\
(606 \cdot 0-1158 \cdot 0)\end{array}$ \\
\hline Men & $\begin{array}{r}240 \\
480 \\
720\end{array}$ & $\begin{array}{c}466 \cdot 4 \\
(327 \cdot 0-730 \cdot 0) \\
934 \cdot 0 \\
(654 \cdot 0-1460 \cdot 0) \\
1400 \cdot 0 \\
(981 \cdot 0-2190 \cdot 0)\end{array}$ \\
\hline
\end{tabular}

*Range of values for five subjects is shown in parentheses.

The excretion of dimethylphenylcarbinol in urine at different intervals of time depending on the amount of absorbed cumene is shown in Table 3.

\section{Kinetics of excreting dimethylphenylcarbinol}

Mean rates of excretion of the metabolite in $\mathrm{mg}$ during the period of 48 hours from the beginning of exposure are given in Table 4. During exposure there was a rapid increase in the rate of excretion of the metabolite, the maximum value being in the urine fraction collected during the last two hours of exposure. When the exposure ceased the rate of excretion decreased, approaching zero after 48 hours.

The correction factor was applied in all experiments so as to compare the course of dimethylphenylcarbinol excretion. Dimethylphenylcarbinol 


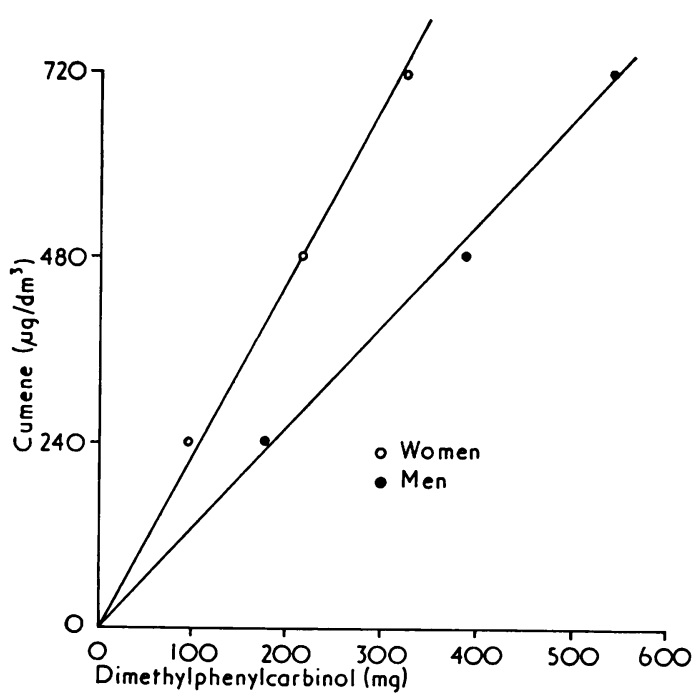

FIG. 5. Dependence between total amount of excreted dimethylphenylcarbinol and concentration of cumene in air.

was found to change according to the different amount of the metabolite and the absorbed cumene dose. The results of all experiments, irrespective of the concentration of cumene vapours in air, have therefore been shown as quotient of the excretion rate of dimethylphenylcarbinol $u$ and absorption rate of cumene $q$.

The mean course of excretion $u / q$ is shown in Fig. 6, and in the semilogarithmic scale in Fig. 7.

Piotrowski $(1962,1963)$ showed that the kinetics
TABLE 4

VARIANTS OF EXPOSURE TESTS

\begin{tabular}{|c|c|c|c|c|}
\hline No. & $\begin{array}{c}\text { Variant of exposure } \\
\text { test }\end{array}$ & $\begin{array}{c}\text { Formu- } \\
\quad \text { lae }\end{array}$ & $\begin{array}{l}\text { Corre- } \\
\text { lation }\end{array}$ & $\begin{array}{c}\text { Varia- } \\
\text { tion } \\
\text { coeffi- } \\
\text { cient } \\
\pm \%\end{array}$ \\
\hline 1 & $\begin{array}{l}\text { Amount of dime- } \\
\text { thylphenylcarbinol } \\
\text { (mg) in urine } \\
\text { collected during } 24 \\
\text { hours (including } \\
\text { exposure time) } \\
\text { Rate of excretion of } \\
\text { dimethylphenyl- } \\
\text { carbinol (mg/h) } \\
\text { during last two } \\
\text { hours of exposure } \\
\text { between sixth and } \\
\text { eighth hour) }\end{array}$ & $\begin{array}{c}y= \\
0 \cdot 36 . x\end{array}$ & 0.98 & \pm 9.5 \\
\hline
\end{tabular}

Formulae $\mathrm{x}=$ dose of absorbed cumene $(\mathrm{mg})$.

$y=$ excretion of dimethylphenylcarbinol in units shown in table.

of excreting dimethylphenylcarbinol could be calculated from part of the curve of Fig. 7 corresponding with the postexposure period. The curve may be resolved graphically into two straight lines, corresponding with a diphasic excretion of dimethylphenylcarbinol. The intersections of the straight lines of both excretion phases with the axis $y$ give the values $\mathrm{K}_{3} \mathrm{C}_{1}=0.3, \mathrm{~K}_{3} \mathrm{C}_{2}=0.048$.

The following were also determined graphically: half life of excretion phase $I P_{I}=$ two hours half life of excretion phase II $P_{I I}=10$ hours.

TABLE 3

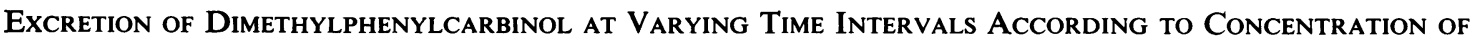
CUMENE IN INHALED AIR

\begin{tabular}{|c|c|c|c|c|}
\hline \multirow[t]{2}{*}{ Sex } & \multirow{2}{*}{$\begin{array}{l}\text { Concentration of } \\
\text { of cumene in } \\
\text { chamber }\end{array}$} & \multicolumn{3}{|c|}{ Mean excretion of dimethylphenylcarbinol $(\mathrm{mg})$} \\
\hline & & $5 \cdot 5-8$ hours & 8-24 hours & $0-48$ hours \\
\hline Women & $\begin{array}{l}100 \\
300 \\
600 \\
100 \\
300 \\
600\end{array}$ & $\begin{array}{c}25 \\
(15 \cdot 5-35 \cdot 4)^{*} \\
58 \cdot 6 \\
(41 \cdot 6-80) \\
88 \cdot 7 \\
(58 \cdot 5-122) \\
42 \cdot 1 \\
(26 \cdot 4-57) \\
78 \cdot 8 \\
(62 \cdot 5-107) \\
120 \cdot 4 \\
(75-163)\end{array}$ & $\begin{array}{c}9 \cdot 1 \\
(6 \cdot 4-11 \cdot 6) \\
25 \cdot 8 \\
(16 \cdot 7-40) \\
42 \cdot 8 \\
(20 \cdot 7-77 \cdot 5) \\
20 \cdot 2 \\
(11 \cdot 7-37 \cdot 7) \\
56 \cdot 8 \\
(23 \cdot 6-121) \\
86 \cdot 5 \\
(50-150)\end{array}$ & $\begin{array}{c}96 \cdot 6 \\
(73-130 \cdot 6) \\
219 \\
(151 \cdot 6-343 \cdot 6) \\
325 \\
(201 \cdot 4-447) \\
2 \cdot 9 \\
(1 \cdot 3-5 \cdot 3) \\
5 \cdot 3 \\
(2 \cdot 7-9 \cdot 6) \\
7 \cdot 4 \\
(2 \cdot 2-16 \cdot 0)\end{array}$ \\
\hline
\end{tabular}

*Range of values for five subjects is shown in parentheses. 
The kinetic equation is given by the formula:

where:

$$
u_{t} / q=\mathrm{K}_{3} \mathrm{C}_{1} e^{-r_{1} t}+\mathrm{K}_{3} \mathrm{C}_{2} e^{-r_{2} t}
$$

$t=$ excretion time after ending the exposure in hours

$e=$ base of natural logarithms

$u=$ excretion rate of dimethylphenylcarbinol (mg/h)

$q=$ absorption rate of cumene $(\mathrm{mg} / \mathrm{h})$

$r_{1}, r_{2}=$ coefficients of I and II excretion phase, respectively.

Substituting the numerical values the following kinetic equation is obtained:

where:

$$
u_{t} / u_{\max }=0.86 e^{-0.35 t}+0.14 e^{-0.07 t}
$$

$u_{\max }=$ the maximum excretion rate found immediately after exposure

$u_{t}=$ the excretion rate at time $t$ hours followthe maximum excretion.

\section{Exposure test}

The excretion of the metabolite may be expressed quantitatively in different units, such as: a full day's excretion, concentration in urine, and rate of excretion.

The empirical values shown in Table 4 were determined from the absorbed cumene dose and quantity of excreted dimethylphenylcarbinol. The dependences found in the different forms of tests are shown in Figs 8 and 9. They are represented by straight lines drawn by means of the regression equation.

For Test 2 the urine had to be collected twice,

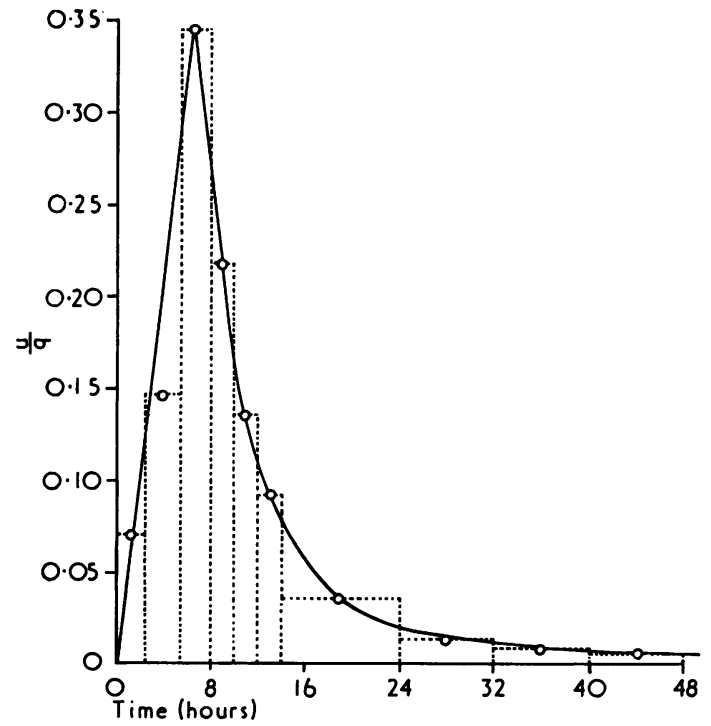

FIG. 6. Dependence between $\frac{u}{q}$ and time.

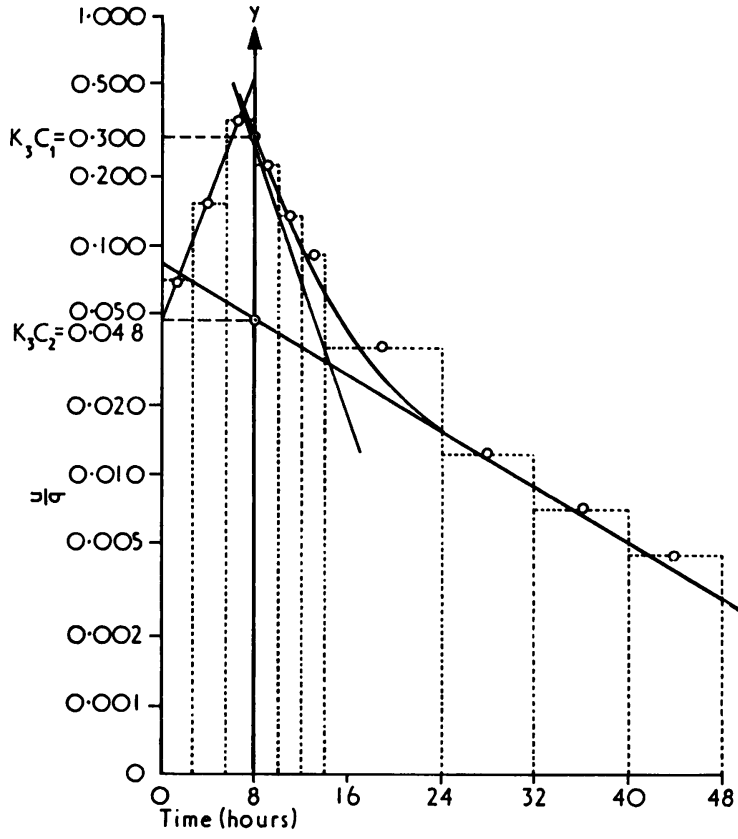

FIG. 7. Dependence between $\frac{u}{q}$ and time (semilogarithmic scale).

after the sixth and eighth hour of work. After six hours the urine was collected so as to empty the bladder. After eight hours of work dimethylphenylcarbinol was determined in the urine; and from the formulae given in the table the absorbed dose of cumene was calculated.

\section{Discussion}

In order to calculate the percentage yield of the conversion of cumene into dimethylphenylcarbinol, all positive results were collected during the 48 -hour period for analysis. The average percentage yield of the conversion thus determined was $35 \%$. The kinetics of excretion of dimethylphenylcarbinol in urine is shown in Table 3. The mean rate of dimethylphenylcarbinol excreted greatly increased during the exposure. It reached the maximum values between the sixth and eighth hour of exposure.

The tests that gave the best results are shown in Table 4. The correlation between the amount of absorbed cumene and the amount calculated by the different methods of specifying excretion, was very close in both tests.

The application of Test 1 is limited in routine examinations, because of the difficulty in collecting urine during a 48-hour period. Endeavours to 


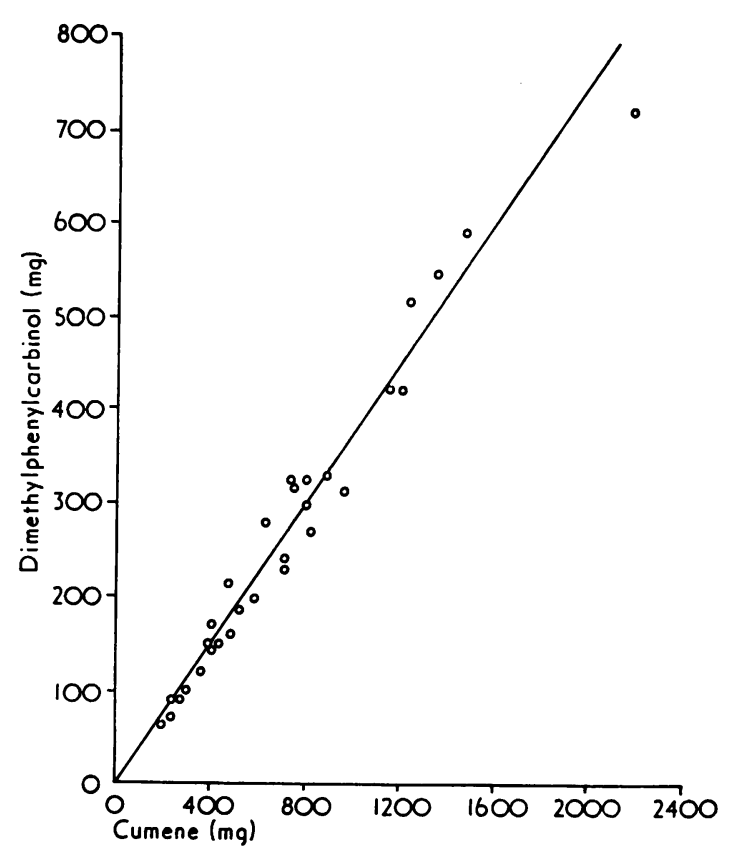

FIG. 8. Dependence between amount of absorbed cumene and amount of dimethylphenylcarbinol excreted during 24 hours.

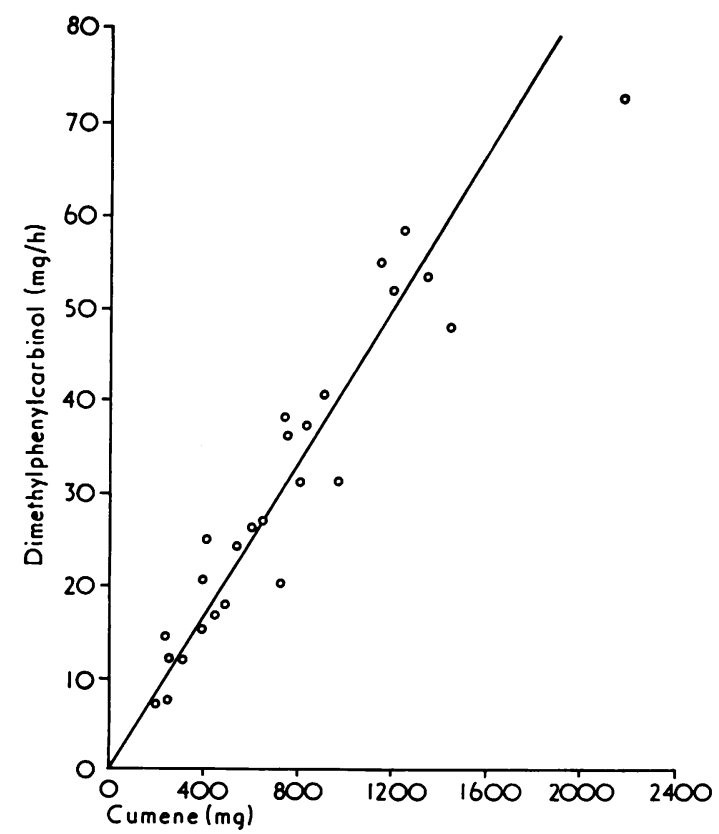

FIG. 9. Dependence between excretion rate of dimethylphenylcarbinol $(\mathrm{mg} / \mathrm{h}$ ) (between sixth and eighth hour of exposure) and absorbed amount of cumene. work out a test based on the concentration of dimethylphenylcarbinol in $\mathrm{g} / \mathrm{cm}^{3}$ urine were not successful as a linear dependence between the absorbed dose of cumene and the concentration of the metabolite in different urine fractions could not be found.

No positive result could be obtained, when trying to correct the concentration to the constant specific gravity $(1.024)$, which confirms the conclusions of Piotrowski $(1967,1971)$ and of Masayuki and Hatsue Ohtsuji (1969) who did not find any linear correlation between the specific gravity of urine and concentration of the metabolite.

\section{References}

Ader, D., Piotrowski, J., and Zaremba, Z. (1958). Chemiczna ocena narazenia na benzynę w przemyśle. Medycyna Pracy, 3, 207-217.

Dutkiewicz, T. (1962). Wchłanianie i metabolizm aniliny u ludzi. Lodzkie Towarzystwo Naukowe, Lódź. (1971). Testy toksykologiczne. Bromatologia $i$ Chemia Toksykologiczna, 1, 39-44.

Masayuki, I. and Hatsue Ohtsuji (1969). Hippuric acid, phenol, and trichloroacetic acid levels in the urine of Japanese subjects with no known exposure to organic solvents. British Journal of Industrial Medicine, 26, 162-164.

Piotrowski, J. (1962). Niektóre zagadnienia kinetyki wydalania trucizn przemysłowych $\mathrm{z}$ ustroju. I. Proste wydalanie jednorazowej dawki substancji obcej. Medycyna Pracy, 4, 273-283.

(1963). Niektóre zagadnienia kinetyki wydalania trucizn przemysłowych $\mathrm{z}$ ustroju. II. Złożone wydalanie jednorazowej dawki substancji obcej. Medycyna Pracy, 1, 61-73.

- (1967). Ilościowa ocena wchłaniania toluenu u ludzi. Medycyna Pracy, 18, 213-223.

- (1971). The application of metabolic and excretion kinetics to problems of industrial toxicology. US Department of Health, Education and Welfare, Washington, D.C.

Robinson, D., Smith, J. N., and Williams, R. T. (1955). Studies in detoxication; metabolism of alkylbenzenes. Isopropylbenzene (cumene) and derivatives of hydratropic acid. Biochemical Journal, 59, 153-159.

Salmowa, J. and Piotrowski, J. (1960). Próba ilościowej oceny wchłaniania nitrobenzenu w warunkach doświadczalnych. Medycyna Pracy, 1, 1-14.

Seńczuk, W. and Litewka, B. (1974). Oznaczanie dwumetylofenylokarbinolu w moczu dla oceny narażenia na zatrucia izopropylobenzenem. Bromatologia i Chemia Toksykologiczna, 1, 93-97.

— and Orłowski, J. (1976). Absorption of m-xylene vapours through the respiratory tract and excretion of m-methylhippuric acid in urine. (To be published).

Received for publication 1 June 1975

Accepted for publication 12 January 1976 